\title{
A Psychoanalytical Study of 'Klaus Mikaelson' in the Trilogy The Originals
}

Khushi Khan

\section{B.A. (Hons.) English Literature}

School of Humanities and Social Science

Jagran Lakecity University

Bhopal, Madhya Pradesh, India

khushikhan.skm@gmail.com

\section{Abstract}

Klaus Mikaelson is a character who always leaves you spellbound. He is actually one of his kind. A hybrid and an original vampire. Moreover, vampires have always been a source of attraction to readers interested in gothic literature. The purpose of this study is to psychoanalytically elucidate the character Klaus Mikaleson in the Trilogy The Originals by Julie Plec. Using psychoanalysis theory, this study analyzed the character more closely and provided us with an even clearer picture of his personality. Klaus Mikaelson's personality changes based on the situation and exposure to varied characters. His personality shifts from a heartless, highly conniving, and cruel character to one who feels remorse and guilt.

Keywords: The Originals, Psychoanalysis theory, Reception, Vampire, Personality Traits. Introduction

Family is power. The Original vampire family swore it to each other a thousand years ago. They pledged to remain together always and forever. But even when you're immortal, promises are hard to keep. (The Originals Trilogy, 2015). 
A vampire is a popular legend, a personage that devours upon humans by swilling their blood. In the recent past, vampires have emerged as the pivotal character in literary works and other media like movies and web series, which has sparked curiosity among the readers and audience alike. The peoples' desire of knowing vampires is just like the vampire's desire of searching for blood. The vampires are extremely fascinating to scrutinize because they possess many human characteristics.

The series The Originals, an adaptation of the work under the same title is authored by Julie Plec. The series is among the most popular series adaptations of a book that focuses on the life of vampires. The plot in both the series and the book has one recurring and interesting character, Klaus Mikaelson, who depicts various psychological traits. Psychoanalytic theory by Sigmund Freud, explains that human behavior is influenced by the interactions between three sections of the mind: id, ego, and superego. According to Freud, an internal psychological conflict experienced in different stages is responsible for the development of a personality. Klaus Mikaelson depicts various psychological traits caused by harbored emotions, memories, experiences, and interactions which determine his behavior in the novel.

The Trilogy comprises of three novels: The Rise, The Loss and The Resurrection and each novel has its own different essence and depiction of Klaus Mikaelson.

The Rise: Arriving in New Orleans in 1722, original vampire siblings Klaus, Elijah and Rebekah Mikaelson believe they've evaded their menacing past. But the town is lawless, a haven for witches and werewolves unwilling to share territory. The siblings are at their lenience ...especially after Klaus meets the gorgeous and mysterious Vivianne. Her impending marriage is significant to ending the war between the supernatural factions - and Klaus's attraction to her could destroy the uneasy alliance. As Elijah slogs toward securing a touch of the town for his family, and Rebekah restrains her unexpected feelings for a French captain, will Klaus's impulsive desires bring their world crashing down — and tear them apart for good? (Plec, 2015) 


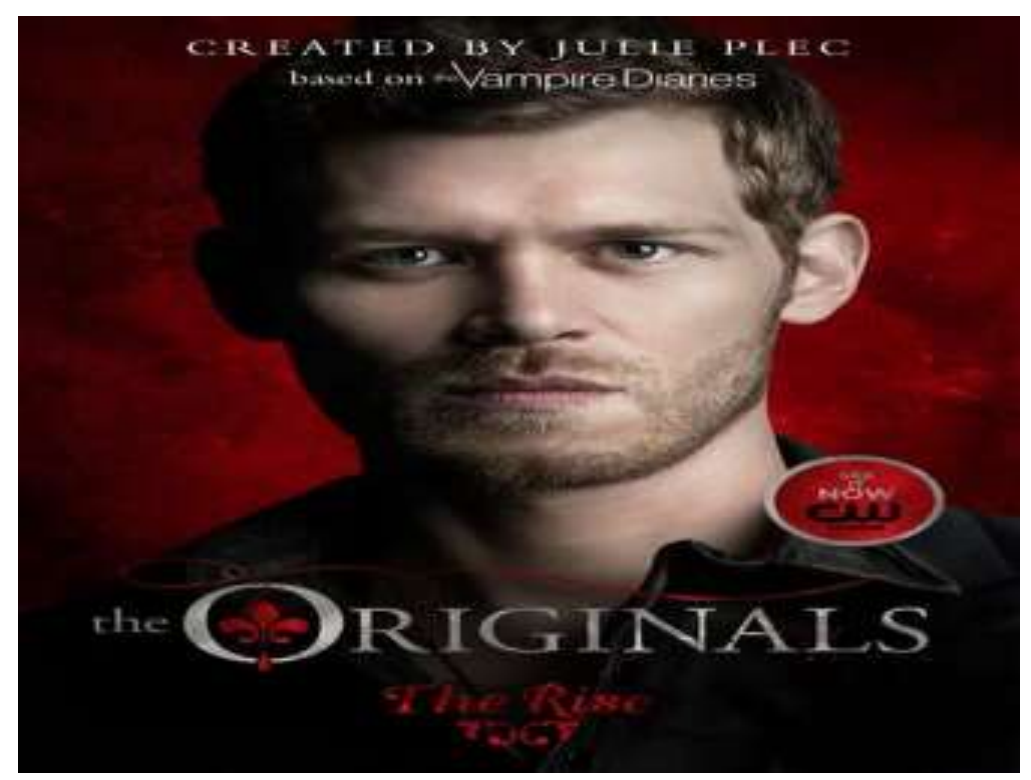

The Loss: After a hurricane dismantled their city, Klaus, Elijah and Rebekah Mikaelson have revamped New Orleans to even greater glory. The year is 1766 . The witches survive the fringes within the bayou. The werewolves have fled. But still, Klaus isn't satisfied. He wants more. He wants power. But when Klaus finally finds a witch who will perform a spell to offer him what he desires most, she secretly uses Klaus to unleash a curse—one that brings back

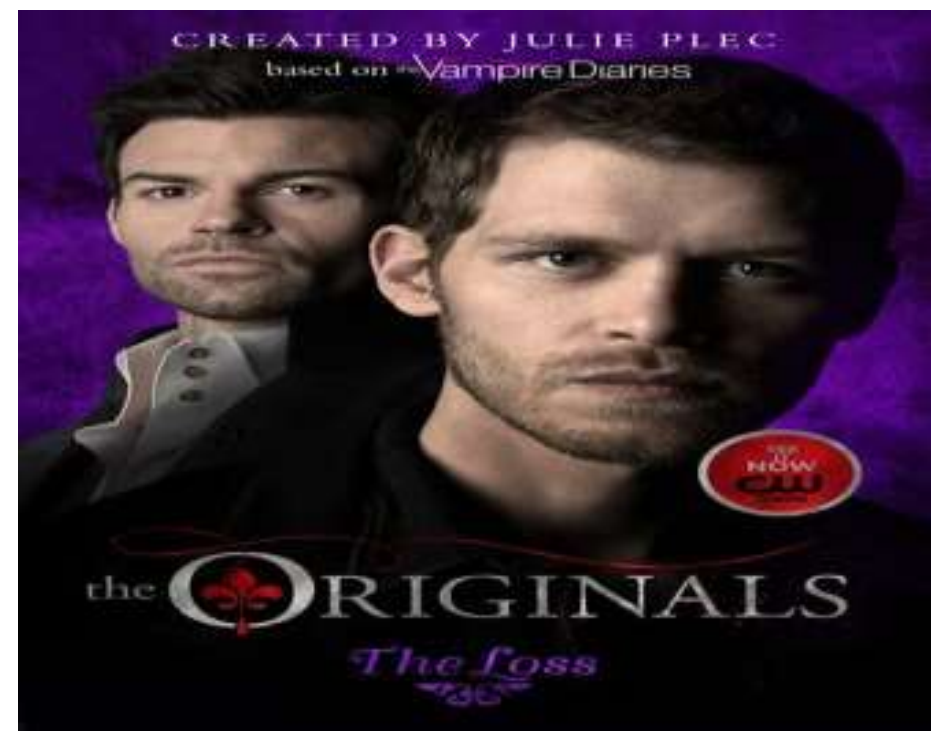

many of her ancestors - and begins a war to reclaim New Orleans. Because the siblings repel the attack, only one thing is for certain — the result is getting to be a bloodbath. (Plec, 2015)

The Resurrection: Klaus, Elijah and Rebekah Mikaelson had won it all, only to break down again by 1788. Control of latest Orleans is split between the vampires and thus the 
werewolves, much to Klaus's displeasure. During a dangerous plan to reclaim his home, Klaus decides to develop a vampire army to need out the werewolves once and for all. If he can't have love, then he'll accept power. Elijah lets his brother take the reins as he turns his attention to a stunning and mysterious woman. But Rebekah has had enough of her brothers' love of bloodshed and begins a journey to hunt out her first home and therefore the key to her family's immortality. Because the battle rages on, the siblings must close and fight for what they believe in the most: family. (Plec, 2015)

Klaus Mikaelson is a character who is very determined, confident, conniving and strategic with a raging temper. He experienced loneliness all his life, and this sense of solitary kills him regularly leaving him in paranoia. He always craved for a family and a sense of love but finds it hard to trust anybody because of the continuous betrayal of his people. There are many reasons as to how a person behaves or reacts, and this is what the research is going to cover. This research is carried out to acquire a deeper understanding of the leading character Klaus Mikaelson. The research primarily aims to analyze the characteristics of Klaus Mikaelson and his psychological aspects by using the psychoanalysis theory.

\section{Psychoanalysis Theory}

Sigmund Freud, who is acclaimed as the father of psychoanalysis, adduces in his theory that an individual's behaviors are superintended by a part of the mind called unconscious. He reveals there are deep and largely unattainable data in this part of the brain which means this kind of data is not easily escorted to the forefront with one's free will. Later, Freud compares the unconscious mind with a conscious and preconscious mind. He defines consciousness as the data in a particular period and preconscious as the data that can easily be escorted to consciousness. These data could be one's thoughts, feelings, perceptions, wishes or memories, and they might exist in one or more. Probing into this triangle, Freud implies that unconscious 
is the big balloon, which covers conscious and preconscious, and everything preconscious and conscious has its own pace in unconscious. (Freud, 1920).

Freud proposed three structures of the true self or the personality. Id, Ego, and Super-Ego. Id refers to a selfish, primitive, childish pleasure -oriented part of the personality with no ability to delay gratification. Superego refers to internalized societal and parental standards of 'good' and 'bad', 'right' and 'wrong' behavior'. Ego refers to the moderator between the Id and Super-Ego which seeks compromises to pacify both. It can be viewed as our 'sense of time and place'.

Psychoanalysis and Literature

Psychoanalysis is not simply a branch of psychology but it also helps us to understand philosophy, culture, religion and first literature. In developing his theory of psychoanalysis Freud has often related it to art in general and to literature in particular. (Hossain, 2017).

In the Interpretation of Dreams, Freud analyzed Sophocles' Oedipus Rex and Shakespeare's Hamlet for their Oedipal elements and the effects that these plays had on their audience. In his Creative Writers and Day-dreaming, Freud further elaborated the interrelation between literature and psychoanalysis. He compared fantasy, play, dreams and therefore the work of art so as to know creativity. Freud first presented his theory on the structure of the literary work and made a psychoanalytic inquiry into the nature of literature. For Freud, a literary work is analogous to a daydream. Like a daydream, the literary work contains in its fantasy the fulfillment of an unsatisfied wish and thus improves on an unsatisfactory reality.

Psychoanalytic literary criticism can specialize in one or more of the following: The author- The idea is employed to analyze the author and his/her life and the literary work. The characters- This idea is employed to analyze one or more of the characters, the psychological theory becomes a tool that elucidates the characters' behavior and motivations. The 
audience-The idea is employed to elucidate the appeal of the work for those who read it. The text- The idea is employed to analyze the role of language and symbolism within the work.

Personality, childhood memories and experiences Klaus Mikaelson was determined to transform his life due to the negative childhood memories involving his family. According to Sigmund's theory, an individual's life as an adult is determined by the events during childhood, which shapes their personality (McLeod, 2018). Plec highlights Klaus Mikaelson's life as one filled with tragedy. In the book, The Rise, Mikaelson's family was slaughtered by his stepfather due to the realization that he was a hybrid (Plec, 2015). As a result, Mikaelson bestows a large part of his life trying to break the curse placed upon him and will do anything to accomplish the task. Klaus's determination is a result of his desire to gain the power to be able to control the outcomes of his life. He was incapable to defend his family while being slaughtered and hence desires to alter the situation. In the Originals, Mikaelson is portrayed as heartless, conniving, and reclusive. He kills without remorse, manipulates people to his advantage, and does not let people into his life. However, his personality is a result of his negative experiences that saw him lose family members as well as the backlash he received alongside his siblings after moving to Vivianne Lescheres's city.

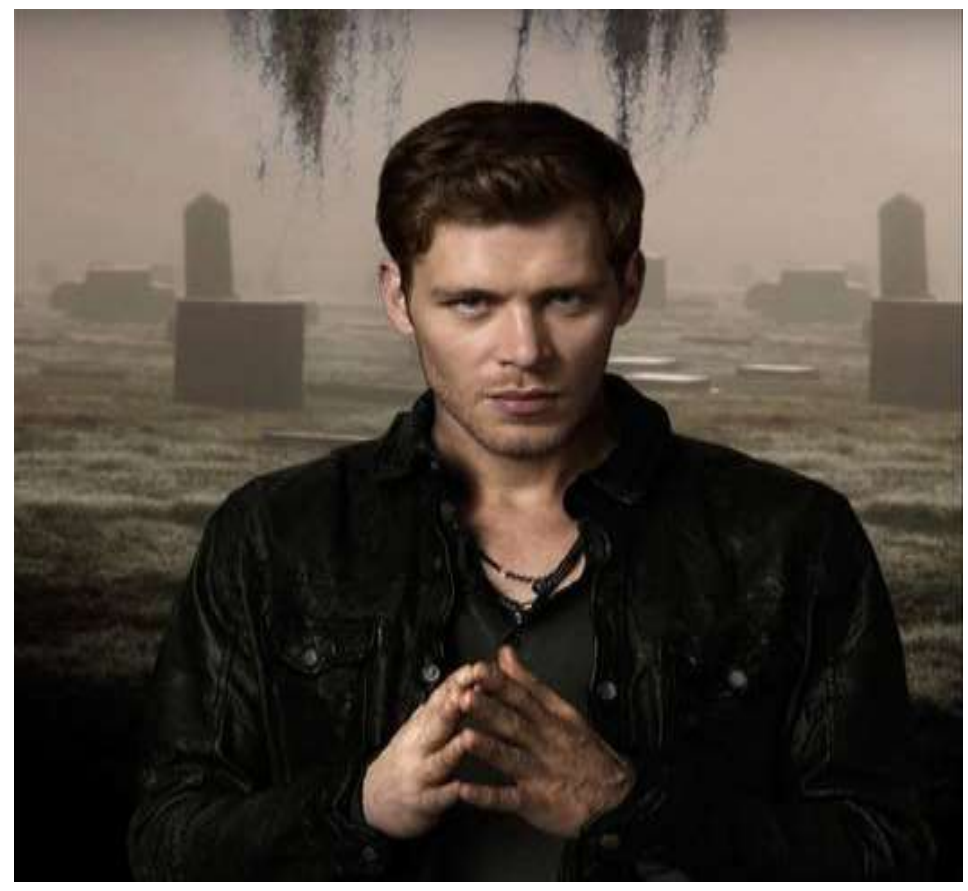


Klaus Mikaelson and Psychoanalysis

Klaus's personality can be explained using Sigmund's components of the mind, particularly the 'id'. According to psychoanalysis, an individual's repressed desires can be exhibited as symptoms, dreams and additional uncontrolled actions (McLeod, 2015). Klaus's life was filled with betrayal and survival from escaping his troubled past to fighting backlash from his new community. In The Resurrection, Mikaelson seeks power through the creation of an army since he believes power tramples everything (Plec, 2015). He wants to compensate for the fear he experiences towards his father. Klaus experienced his stepfather's most destructive side as a child through physical and verbal abuse. Klaus admits Mikael is his worst fear, which compels him to constantly seek validation from him. He has been unexposed to love hence, seizes power as the only option for his survival.

Sigmund's psychoanalysis theory notes that the three states of the mind are constantly in conflict with each one desiring to accomplish its prime objective. A greater conflict between the three states creates a situation where the 'ego' adopts defense mechanisms to safeguard the individual (McLeod, 2018). Klaus Mikaelson's ego uses denial as a way to block unwanted feelings or overwhelming experiences. Klaus is in denial regarding his feelings of guilt and remorse towards his actions as well as his morals since he believes he cannot love and is unwanted. However, regardless of the negative personality, Klaus protects his younger half-sister, Rebekah for centuries and also ends up gaining paternal instincts after the birth of his child. He focuses on protecting his family, regardless of the cost but still portrays himself as one that does not care about the life of anyone else but himself as shown in The Loss (Plec, 2015). Hence, Klaus's personality changes based on the situation and exposure to varied characters. 


\section{Conclusion}

Klaus Mikaelson's personality is a result of the conflicting states of the 'ego', 'superego', and 'id'. Mikaelson's personality emerges from his childhood memories and experiences as well as his reception from the community he visits. Hence, his personality shifts from a heartless, conniving and cruel character to one who feels remorse and guilt. The change is supported by Freud Sigmund's theory that links childhood experiences to the personality of an individual as an adult. 


\section{Works Cited}

Freud, Sigmund. Interpretation of Dreams. 1913. 3rd edition, Translated by Brill A A. Macmillan.

---. “Dream psychology.” Psychoanalysis for Beginners. 1920. Translated by M D. Eder

Hossain, Mahroof. "Psychoanalytic Theory used in English Literature: A Descriptive Study. "Global Journal of Human Social Science: G Linguistics \& Education. Vol 17, No. 1, 2017.

McLeod, Saul. "What are the most interesting ideas of Sigmund Freud?”, Feb 5, 2018. www.simplypsychology.org/Sigmund-Freud.html

Michael, C. Gibson, “Defence Mechanism.”, Wikidoc, Sept 4, 2012 b. www.wikidoc.org/index.php/Defence_mechanism

Plec, Julie. The Originals: The Rise. HQN Books, 2015. www.harlequin.com/shop/books/9781460349731_the-originals-the-rise.html

---.The Originals: The Resurrection. HQN Books, 2015. www.harlequin.com/shop/books/9781460349731_the-originals-the-resurrection.html ---.The Originals: The Loss. HQN Books, 2015. www.harlequin.com/shop/books/9781460349731_the-originals-the-loss.html 